\title{
GUBITAK STABILNOSTI I ODREĐIVANJE NOSIVOSTI ČELIČNOG HIDRAULIČNOG PODUPIRAČA
}

\author{
Nina Mujkanović \\ Sveučilište u Zagrebu, Građevinski fakultet, univ.bacc.ing.aedif. \\ Joško Krolo \\ Sveučilište u Zagrebu, Građevinski fakultet, prof.dr.sc.
}

Sažetak: Hidraulični podupirač prvenstveno je namijenjen uporabi u građevinarstvu, ali svoju primjenu može naći i u drugim područjima poput rudarstva ili brodogradnje. Konstrukcija ovog hidrauličnog podupirača razlikuje se od klasičnog po tome što umjesto dvije cijevi ima tri, a u najdonjoj, baznoj cijevi, ima ugrađenu hidrauličnu dizalicu. U ovome radu utvrđena je nosivost takvog hidrauličnog podupirača analitičkim rješenjem diferencijalne jednadžbe, proračunom prema euronormi 3 i metodom konačnih elemenata (SOFiSTiK). Ta rješenja su uspoređena $\mathrm{s}$ nosivošću dobivenom eksperimentalnim putem.

Ključne riječi: hidraulični podupirač, gubitak stabilnosti, nosivost, euronorma 3, MKE, eksperiment

\section{LOSS OF STABILITY AND DETERMINATION OF BEARING CAPACITY OF THE STEEL HYDRAULIC PROP}

\begin{abstract}
Hydraulic prop is chiefly intended for use in the field of civil engineering, but its aplication can be found in other areas such as mining and shipbuilding. The construction of the hydraulic prop is different from the classic in the way that it has three tubes instead of two, and the lowest, base tube, has a built-in hydraulic crane. In this scientific work bearing capacity of the hydraulic prop is determined by analytical solution of differential equations, calculations according to Eurocode 3 and finite element method (SOFiSTiK). These solutions are compared with the experimentally obtained bearing capacity.
\end{abstract}

Key words: hydraulic prop, loss of stability, bearing capacity, EUROCODE 3, FEM, experiment 


\section{Uvod}

Hidraulični čelični podupirač od klasičnog podupirača se razlikuje po tome što umjesto dvije cijevi ima tri, s tim da u najdonjoj, baznoj cijevi, ima ugrađenu hidrauličnu dizalicu (slika 1). Namijenjen je prvenstveno uporabi u građevinarstvu, a svoju primjenu može naći i u rudarstvu, brodogradnji i dr. Njegove prednosti pred klasičnim podupiračem su brojne. Jednostavno se postavlja tako da se postavljanje i niveliranje na željenu, precizno u milimetrima određenu visinu, može obaviti vrlo brzo.

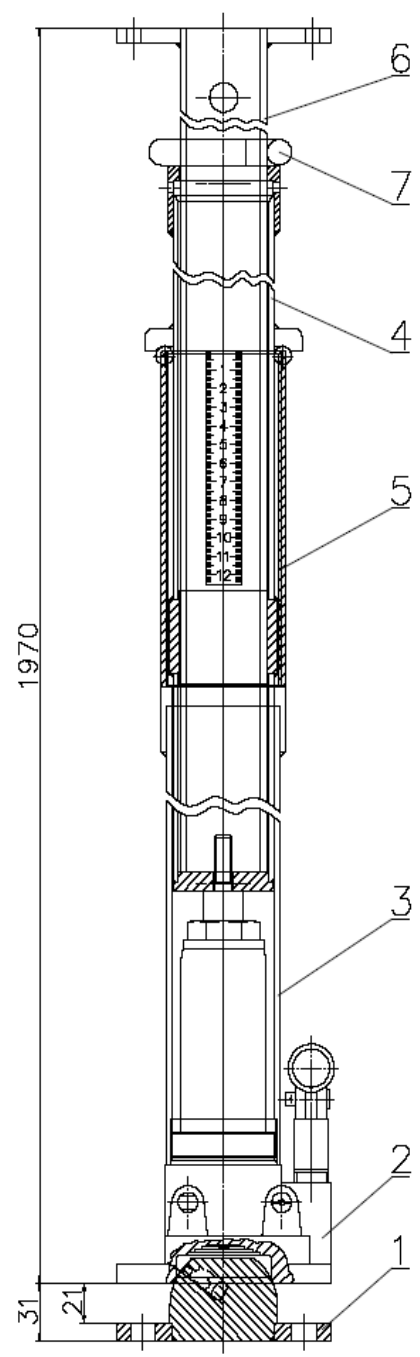

Slika 1 - Dijelovi hidrauličnog podupirača: 1) zglob, 2) hidraulična dizalica, 3) osnovna cijev, 4) radna cijev, 5) matica Tr64×8, 6) gornja cijev, 7) osigurač

Demontaža pri skidanju oplate također je vrlo jednostavna, lagana i bez opasnosti od ozljeda ili oštećenja podupirača. Za postavljanje podupirača potreban je manji broj djelatnika, odnosno manji broj sati, što dovodi do smanjenja troškova građenja i uštede na vremenu postavljanja oplate. $U$ idealnim uvjetima, pri njegovom postavljanju i demontaži nema torzije niti poprečnih sila kao na klasičnom podupiraču, pa nije potrebno njegovo fiksiranje za podlogu na koju se postavlja, niti gornjeg dijela za element koji leži na njemu.

Prilikom rekonstrukcija građevina i niveliranja težih masa, koje je potrebno podignuti na određenu visinu, nema potrebe za mukotrpnim okretanjem matice ili podbijanjem klinova, već se to vrlo lako i precizno postiže 
hidraulikom. Vrlo je važno napomenuti da teret ne nosi hidraulika. Ona služi samo za podizanje na željenu visinu, a nakon toga matica svojim oslanjanjem na cijev baze preuzima cjelokupan teret dok se hidraulika otpušta.

Hidraulički podupirač ima dvije skale koje služe preciznom namještanju visine. Na gornjoj cijevi utisnuta je skala od po $10 \mathrm{~cm}$ koja označava visinu koju podupirač ima kada se u rupu, pokraj koje je brojka, postavi osigurač. Na srednjoj cijevi, ispod matice, ima skalu u milimetrima za precizno namještanje visine podupirača. Visina na koju je postavljen podupirač predstavlja zbroj mjere na gornjoj cijevi i mjere koju otkriva rub matice na srednjoj cijevi. Maksimalna visina podupirača je $I_{\max }=3,50 \mathrm{~m}$ i izrađen je od čelika klase S235.

Hidraulični podupirač je naročito prikladan za radove na visokim halama gdje se podupirači postavljaju na 10 i više metara. Da bi se izvršilo niveliranje visine kod klasičnog podupirača, potrebno je imati skelu. Kod hidrauličnog nema potrebe za dodatnom skelom, jer se namještanje visine lagano izvršava uporabom hidraulike koja je smještena pri dnu podupirača. Kako nema potrebe za nasilnim udaranjem kod zatezanja i otpuštanja matice, što kod klasičnih podupirača smanjuje vijek uporabe, hidraulični podupirač ima puno duži vijek uporabe čime se također pridonosi smanjenju troškova građenja.

\section{Proračun nosivosti podupirača}

\subsection{Izračun geometrijskih karakteristika cijevi}

Prema oznakama na slici 2, u tablici 1 prikazane su izračunane geometrijske karakteristike gornje i radne cijevi podupirača [1].

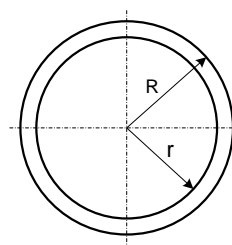

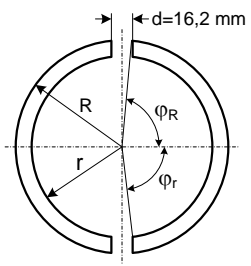

b)

Slika 2 - Poprečni presjek cijevi a) bruto b) neto

Tablica 1 - Geometrijske karakteristike cijevi

\begin{tabular}{|c|c|c|c|}
\hline $\begin{array}{c}\text { Geometrijska } \\
\text { karakteristika }\end{array}$ & Gornja cijev - bruto & Gornja cijev - neto & Radna cijev \\
\hline $\begin{array}{c}\text { Vanjski } \\
\text { polumjer }\end{array}$ & $\mathrm{R}=24,15 \mathrm{~mm}$ & $\mathrm{R}=24,15 \mathrm{~mm}$ & $\mathrm{R}=28,00 \mathrm{~mm}$ \\
\hline $\begin{array}{c}\text { Unutarnji } \\
\text { polumjer }\end{array}$ & $\mathrm{r}=20,65 \mathrm{~mm}$ & $\mathrm{r}=20,65 \mathrm{~mm}$ & $A_{\mathrm{br}}=420,19 \mathrm{~mm}^{2}$ \\
\hline $\begin{array}{c}\text { Ploština } \\
\text { cijevi }\end{array}$ & $\mathrm{A}_{\mathrm{br}}=492,6 \mathrm{~mm}^{2}$ & $A_{\text {neto }}=377,80 \mathrm{~mm}^{2}$ & $\mathrm{I}_{\mathrm{br}}=150,66 \times 10^{3} \mathrm{~mm}^{4}$ \\
\hline $\begin{array}{c}\text { Moment } \\
\text { inercije }\end{array}$ & $\mathrm{I}_{\mathrm{br}}=124,34 \times 10^{3} \mathrm{~mm}^{4}$ & $\mathrm{I}_{\text {neto }}=69,22 \times 10^{3} \mathrm{~mm}^{4}$ & $W_{\mathrm{br}}^{\mathrm{el}}=\mathbf{5 3 8 0 , 8 5} \mathbf{m m}^{\mathbf{3}}$ \\
\hline $\begin{array}{c}\text { Moment } \\
\text { otpora u } \\
\text { elastičnom } \\
\text { području }\end{array}$ & $W_{\mathrm{br}}^{\mathrm{el}}=\mathbf{5 1 4 8 , 5 8} \mathbf{m m}^{\mathbf{3}}$ & $W_{\mathbf{n}}^{\mathrm{el}}=\mathbf{3 0 3 7}, \mathbf{7 3} \mathbf{m m}^{\mathbf{3}}$ & \\
\hline
\end{tabular}




\begin{tabular}{|c|c|c|c|}
\hline $\begin{array}{c}\text { Moment } \\
\text { otpora } \\
\text { plastičnosti }\end{array}$ & $W_{\mathrm{br}}^{\mathrm{pl}}=6435,73 \mathrm{~mm}^{3}$ & $W_{\mathrm{n}}^{\mathrm{pl}}=4530,67 \mathrm{~mm}^{3}$ & $W_{\mathrm{br}}^{\mathrm{pl}}=6726,06 \mathrm{~mm}^{3}$ \\
\hline
\end{tabular}

Geometrijske karakteristike poprečnog presjeka cijevi izračunane su preko sljedećih izraza [1]:

$$
\begin{gathered}
A_{\mathrm{br}}=\pi\left(R^{2}-r^{2}\right) ; \quad I_{\mathrm{br}}=\frac{\pi}{4}\left(R^{4}-r^{4}\right) \\
A_{\text {neto }}=\llbracket 2\left(\varphi_{R} R^{2}-\varphi_{r} r^{2}\right)-d\left(R \sin \rrbracket \varphi_{R}-r \sin \varphi_{r}\right) \\
\varphi_{R}=\frac{\arccos d}{2 R} ; \quad \varphi_{r}=\frac{\arccos d}{2 r} \\
W_{\mathbf{n}}^{\mathrm{el}}=\frac{I_{\text {neto }}}{R \sin \varphi_{R}} ; W_{\mathbf{n}}^{\mathrm{pl}}=\frac{4}{3}\left[R^{3}\left(1-\cos \varphi_{R}\right)-r^{3}\left(1-\cos \varphi_{r}\right)\right]-\frac{1}{3} d\left(R^{2} \sin ^{2} \varphi_{R}-r^{2} \sin ^{2} \varphi_{r}\right) \\
W_{\mathrm{br}}^{\mathrm{el}}=\frac{I_{\mathrm{br}}}{R} \quad ; \quad W_{\mathrm{br}}^{\mathrm{pl}}=1,25 \cdot W_{\mathrm{br}}^{\mathrm{el}}
\end{gathered}
$$

\subsection{Diferencijalna jednadžba podupirača [2]}

Pri određivanju diferencijalne jednadžbe podupirača, u obzir se uzima početna imperfekcija. Ona se sastoji od tri dijela (slika 3):

- $\quad$ ekscentricitet zbog spoja dviju cijevi $\left(w_{1}\right)$

- $\quad$ ekscentricitet zbog rubnih uvjeta $\left(e_{0}\right)$

- ekscentricitet zbog zakrivljenosti cijevi $\left(w_{2}\right)$.

Opći oblik diferencijalne jednadžbe elastične linije štapa:

$$
E I \cdot w^{\mathrm{m}}(x)=-M
$$

Ukupni moment savijanja sastoji se od momenta zbog početne nesavršenosti (imperfekcije):

$$
M_{0}=F \cdot e_{0}+F \cdot w_{1}(x)+F \cdot w_{2}(x)
$$

i momenta nastalog zbog opterećenja, tako da je ukupni moment:

$$
M=M_{0}+F \cdot w(x)
$$

Konačno, diferencijalna jednadžba elastične linije podupirača glasi:

$$
E I \cdot w^{\mathrm{I}}(x)=-F \cdot w(x)-F \cdot\left[e_{1} 0+w_{1} 1(x)+w_{1} 2(x)\right]
$$




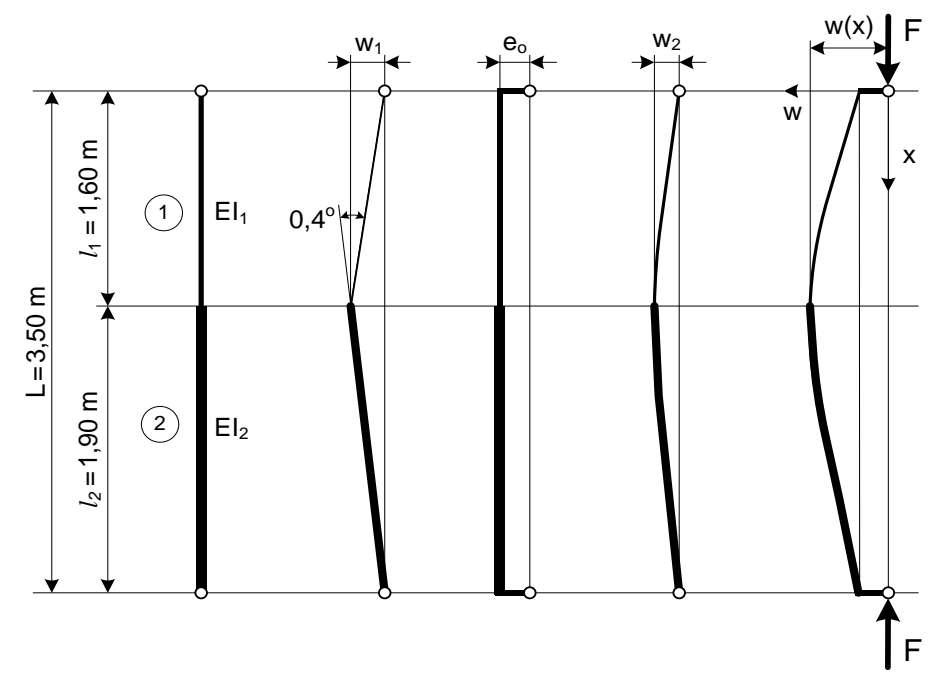

Slika 3 - Prikaz ekscentriciteta

\subsection{Analitičko rješenje problema}

Obrađuje se idealno ravan štap bez geometrijskih i strukturalnih nesavršenosti. Omjer aksijalnih momenata tromosti druge $(\varnothing 56,0 \times 2,5)$ i prve cijevi $(\varnothing 48,3 \times 3,5)$ :

$$
\frac{l_{2}}{l_{1}}=\frac{150,66 \times 10^{3}}{124,34 \times 10^{3}}=1,21=k \text {. }
$$

$$
I_{2}=k \cdot I_{1}
$$

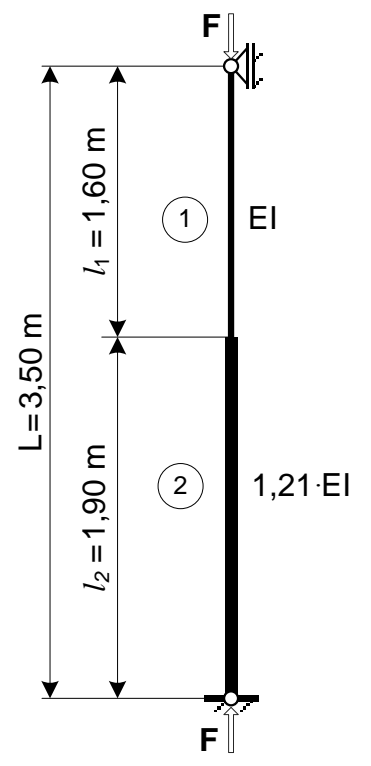

\section{Slika 4 - Model podupirača}

Diferencijalne jednadžbe za donju i radnu cijev podupirača glase:

$$
E I \cdot \frac{\mathrm{d}^{2} w_{1}}{\mathrm{~d} x^{2}}+F \cdot w_{1}=0 ; k \cdot E I \cdot \frac{\mathrm{d}^{2} w_{2}}{\mathrm{~d} x^{2}}+F \cdot w_{2}=0
$$


Ako se označi:

$$
\frac{F}{1,21 \times E I}=k \cdot \alpha^{2},
$$

iz izraza (11) dobije se:

$$
\frac{\mathrm{d}^{2} w_{1}}{\mathrm{~d} x^{2}}+k \cdot \alpha^{2} w_{1}=0 \quad ; \quad \frac{\mathrm{d}^{2} w_{2}}{\mathrm{~d} x^{2}}+\alpha^{2} w_{2}=0 .
$$

Opće rješenje prve diferencijalne jednadžbe je:

ili

$$
w_{1}=A_{1} \sin (\sqrt{k} \alpha x)+B_{1} \cos (\sqrt{k} \alpha x)
$$

a druge:

$$
w_{1}=A_{1} \sin (1,1 \alpha x)+B_{1} \cos \left(1_{s} 1 \alpha x\right),
$$

$$
w_{2}=A_{2} \sin (\alpha x)+B_{2} \cos (\alpha x) .
$$

Ako uzmemo da je približno $l_{1}=l_{2}=/ / 2$, postoje četiri uvjeta od kojih su dva rubna uvjeta i dva uvjeta kontinuiteta:

$$
\begin{gathered}
w_{1}(0)=0 \\
w_{1}\left(\frac{l}{2}\right)=w_{2}\left(\frac{l}{2}\right) \\
w_{1}^{\prime}\left(\frac{l}{2}\right)=w_{2}^{s}\left(\frac{l}{2}\right) \\
w_{2}(l)=0
\end{gathered}
$$

Iz prvog rubnog uvjeta (17) dobivamo $B_{1}=0$. Uvrštavajući drugi rubni uvjet (19) te uvjete kontinuiteta (17) i (18) u opća rješenja diferencijalnih jednadžbi (14) i (15), nakon sređivanja dobiva se sustav od četiri homogene jednadžbe. Da bi sustav homogenih jednadžbi imao rješenje različito od trivijalnog, determinanta sustava mora biti jednaka 0:

$$
\left[\begin{array}{ccc}
\sin (0,55 \alpha l) & -\sin \left(\frac{\alpha l}{2}\right) & -\cos \left(\frac{\alpha l}{2}\right) \\
1,1 \cos (0,55 \alpha l) & -\cos \left(\frac{\alpha l}{2}\right) & \sin \left(\frac{\alpha l}{2}\right) \\
0 & \sin (\alpha l) & \cos (\alpha l)
\end{array}\right]=0
$$

Determinanta je riješena u programu Wolfram Alpha* [3]. Prikazan je postupak unosa podataka u program i ispis rješenja. Mjerodavno je najmanje pozitivno rješenje različito od nule, jer ono daje najmanju vrijednost kritične sile:

$x=\alpha=0,852$.

Koristeći izraz (10), dobije se vrijednost kritične sile $F_{k r}$ :

$F_{\mathrm{kr}}=\alpha^{2} \cdot 1,21 \cdot E \cdot I=0,852^{2} \cdot 1,21 \cdot 2,1 \cdot 10^{8} \cdot 12,43 \cdot 10^{-8}=22,9 \mathrm{kN}$ 


\section{WolframAlphä PRO}

$-\sin \left(1.93^{*} \mathrm{x}\right) * \cos \left(1.75^{*} \mathrm{x}\right) * \cos \left(3.5^{*} \mathrm{x}\right)-\sin \left(1.93^{*} \mathrm{x}\right) * \sin \left(1.75^{*} \mathrm{x}\right) * \sin \left(3.5^{*} \mathrm{x}\right)+1.1^{*} \sin ($

圆一的田-

$\equiv$ Examples $=\{$ Random

\section{Input:}

$-\sin (1.93 x)(\cos (1.75 x) \cos (3.5 x))-$

$\sin (1.93 x) \sin (1.75 x) \sin (3.5 x)+1.1 \sin (1.75 x) \cos (1.93 x) \cos (3.5 x)-$

$1.1 \cos (1.75 x) \cos (1.93 x) \sin (3.5 x)=0$

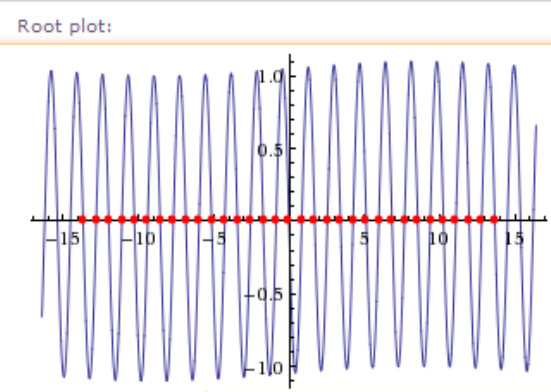

$$
\begin{aligned}
& \mathrm{Q} \pm \mathrm{A} G< \\
& \text { Numerical solutions: } \\
& x \approx-3.42225200833702 \ldots \\
& x \approx \pm 2.55533632714938 \ldots \\
& x \approx \pm 1.71131068293600 \ldots \\
& x \approx \pm 0.851717586232227 \ldots \\
& x=0
\end{aligned}
$$

Slika 5 - Rješenje determinante u programu Wolfram Alpha*

Opći izraz za kritičnu silu je:

$$
F_{\mathrm{kr}}=\frac{\pi^{2} \cdot E \cdot I}{\left(\mu \cdot l^{2}\right.}
$$

pa se iz izraza (21) dobije koeficijent duljine izvijanja štapa:

$$
\mu=\sqrt{\frac{\pi^{2} \cdot E \cdot I}{F_{\mathrm{kr}} \cdot l^{2}}}=0,95 .
$$

Tako duljina izvijanja štapa iznosi: $l_{\mathrm{i}}=\mu \cdot l=0,95 \cdot 3,50=3,33 \mathrm{~m}$.

Naprezanja koja se javljaju pri kritičnoj sili:

- na dijelu bruto poprečnog presjeka iznose:

$$
\sigma_{\mathrm{gr}}=\frac{F_{\mathrm{kr}}}{A_{\mathrm{gr}}}=\frac{22,9 \cdot 10^{3}}{492}, 6=46,5 \mathrm{MPa}
$$


- a na dijelu neto poprečnog presjeka:

$$
\sigma_{\mathrm{n}}=\frac{F_{\mathrm{kr}}}{A_{\text {neto }}}=\frac{22,9 \cdot 10^{3}}{377}, 8=60,6 \mathrm{MPa} .
$$

Ostvareno najveće naprezanje znatno je manje od granice tečenja materijala $\left(f_{y}=235 \mathrm{MPa}\right)$.

\subsection{Normirani postupak dokazivanja stabilnosti podupirača}

Dokaz stabilnosti podupirača normiran je hrvatskom normom HRN EN 1065:2002 [1]. Dokazivanje se provodi utvrđivanjem granične otpornosti tlačnog štapa koji se sastoji od dviju mehanički spojenih cijevi. Provodi se po teoriji drugog (ili višeg) reda uzimajući u obzir početne geometrijske imperfekcije.

Početna nesavršenost određena je preko tri uzroka:

- ekscentricitet zbog spoja dviju cijevi

- ekscentricitet zbog rubnih uvjeta

- ekscentricitet zbog zakrivljenosti cijevi.

\subsubsection{Ekscentricitet zbog spoja dviju cijevi}

Gornja cijev u zoni preklopa nije prislonjena na donju cijev, nego između njih postoji zazor koji uzrokuje pojavu kuta zaokreta između dvije cijevi. Zbog zaokreta cijevi nastaje progib koji se očituje kao dio početne nesavršenosti.

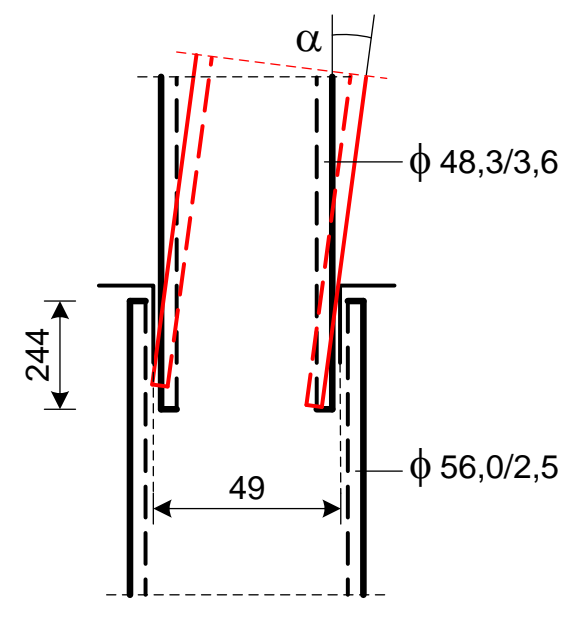

\section{Slika 6 - Zaokret cijevi zbog zazora između cijevi}

Iz uvjeta prikazanih na slici 6, određen je kut zaokreta koji iznosi:

$\alpha=\operatorname{arctg}[(49,0-48,3)+(51,0-48,3)] / 2 / 244=\operatorname{arctg}(1,70 / 244)=0,4^{\circ}$.

Ekscentricitet zbog kuta zaokreta (slika 7) određen je rješavanjem sustava jednadžbi:

$$
\tan \alpha_{g}=1,6=\tan \alpha_{d}=1,9
$$




$$
a_{g}+a_{d}=0,4^{\circ}
$$

Uz uvažavanje jednadžbe (23), jednadžba (22) je transcedentna, pa su iteracijom dobiveni kutevi $\alpha_{\mathrm{g}}$ i $\alpha_{\mathrm{d}}$, odnosno maksimalna vrijednost ekscentriciteta zbog spoja dvije cijevi, koja iznosi: $w_{1}=6,0 \mathrm{~mm}$.

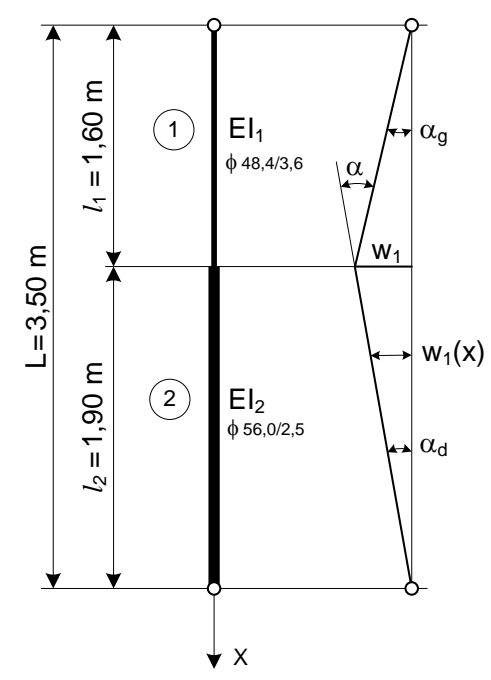

Slika 7 - Ekscentricitet zbog kuta zaokreta

\subsubsection{Ekscentricitet zbog rubnih uvjeta}

Ležajni ekscentricitet, zadan normom HRN EN 1065:2002, nalazi se na gornjem i donjem kraju podupirača. Na gornjem kraju ekscentricitet iznosi $e_{0}=10,0 \mathrm{~mm}$. Na donjem kraju ekscentricitet je zadan složenim uvjetima (slika 8) te se pojednostavljuje i usvaja $e_{b, 0}=10,0 \mathrm{~mm}$.

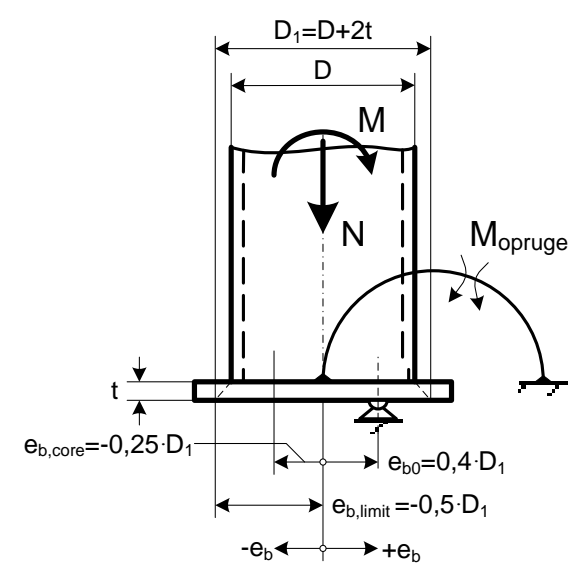

Slika 8 - Ekscentricitet na mjestu oslanjanja cijevi

\subsubsection{Ekscentricitet zbog zakrivljenosti cijevi}

Osi cijevi nisu idealno ravne. Prema [1], zakrivljene su u obliku sinusne funkcije s maksimalnim ekscentricitetom na mjestu spoja dviju cijevi: 


$$
w_{2}=\frac{l}{500} .
$$

Duljina podupirača, u položaju kada je najviše izvučen, iznosi $I=3500 \mathrm{~mm}$ pa je maksimalna vrijednost ekscentriciteta zbog zakrivljenosti cijevi:

$$
w_{2}=\frac{3500}{500}=7,0 \mathrm{~mm}
$$

\subsection{Rezultati proračuna u računalnom programu SOFiSTiK [4]}

Proračun je proveden uz pretpostvaku linearno elastičnog materijala sa svrhom dobivanja sile kod koje podupirač gubi stabilnost. Kao rezultat, dobiven je dijagram sila - pomak (slika 8) za poprečni presjek (čvor) na mjestu spoja gornje i donje cijevi. U proračunu je uzeta u obzir ukupna početna nesavršenost:

$$
w(x)=e_{0}+w_{1}(x)+w_{2}(x),
$$

gdje je $e_{0}=10 \mathrm{~mm}$, a prema slici 7 slijedi:

$w_{1}(x=0$ do 1,60$)=\frac{6}{1600} x \quad ; \quad w_{1}(x=1,6$ do $3,5 m)=\frac{6}{1900(3500-x)}$

Ekscentricitet kao funkcija koordinate $x$ zbog zakrivljenosti cijevi, prema [1] iznosi:

$w_{2}(x)=7 \sin \frac{\pi x}{l}$

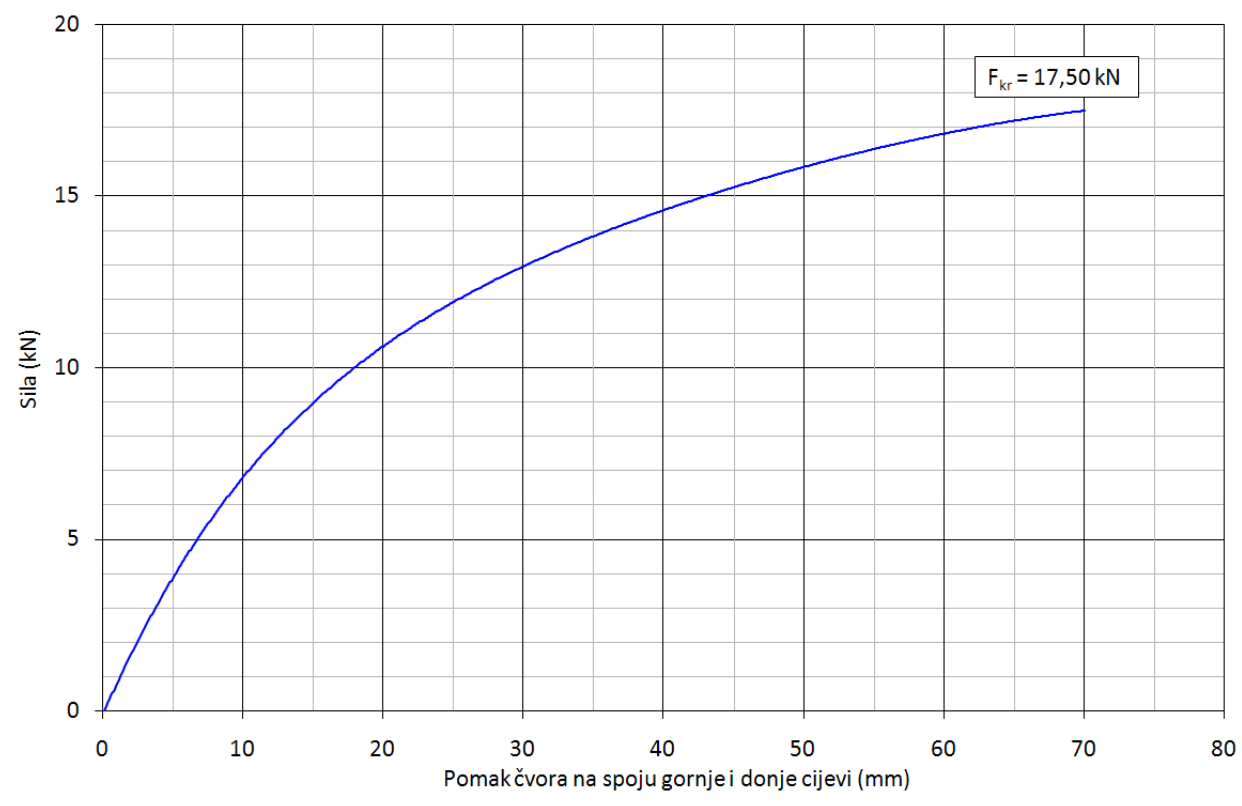

Slika 9 - Dijagram sila - pomak dobiven programom SOFiSTiK

Izračunano je naprezanje za kritično stanje (tablica 2) prema formuli: 


$$
\sigma=\frac{F}{A} \pm \frac{M}{W}
$$

\section{Tablica 2 - Vrijednost kritične sile i pripadnog naprezanja}

\begin{tabular}{|c|c|c|}
\hline $\begin{array}{c}\text { Kritična sila } \\
\mathrm{F}_{\mathrm{kr}}(\mathrm{kN})\end{array}$ & Naprezanje $(\mathrm{MPa})$ & Naprezanje $(\mathrm{MPa})$ \\
\cline { 2 - 3 } & (bruto ploština) & (neto ploština) \\
\hline \multirow{2}{*}{17,50} & Tlak: $\sigma_{1}=-350,2$ & Tlak: $\sigma_{1}=-579,6$ \\
\cline { 2 - 3 } & Vlak: $\sigma_{2}=279,1$ & Vlak: $\sigma_{2}=487,0$ \\
\hline
\end{tabular}

\subsection{Kodificirani proračun prema europskoj normi [5] [6]}

Proračun se provodi prema europskoj normi HRN EN 1993-1-1:2008, a na temelju geometrijskih i statičkih veličina bruto poprečnog presjeka profila $\varnothing 48,3 \times 3,5$, koje se nalaze u tablici 1 .

Na temelju odnosa $\frac{d}{t}=\frac{48,3}{3,5}=13,8<50 \varepsilon^{2}=50 \cdot 1,0=50,0 \quad$ klasifikacijom je poprečni presjek svrstan u klasu 1.

Karakteristična otpornost elementa na izvijanje:

$$
N_{b, k}=x \cdot A \cdot f_{y}
$$

Duljina izvijanja izračunana je u točki 2.3. i iznosi: $l_{i}=333 \mathrm{~cm}$.

Radijus inercije:

$$
i=\sqrt{\frac{I_{\mathrm{br}}}{A_{\mathrm{br}}}}=\sqrt{12, \frac{43}{4}, 93}=1,59 \mathrm{~cm} .
$$

Iz podataka o duljini izvijanja i radijusu inercije, određuje se vitkost podupirača koja iznosi:

$$
\lambda=\frac{l_{\mathrm{i}}}{i}=\frac{333}{1}, 59=209,43 \text {. }
$$

Za čelik S235 vrijedi: $\lambda_{1}=93,9 \times \varepsilon=93,9 \cdot 1,0=93,9$.

Svedena vitkost iznosi:

$$
\bar{\lambda}=\frac{\lambda}{\lambda_{1}}=\frac{209,43}{93,9}=2,23 .
$$

Hladnooblikovani elementi imaju liniju izvijanja "c" te je faktor imperfekcije: $a=0,49$.

Za $\phi=0,5\left[1+\alpha(\bar{\lambda}-0,2)+\overline{\lambda^{2}}\right]=3,76$ koeficijent redukcije otpornosti iščitan je iz Tablice VIII.-21. u [5] i iznosi $\chi=0,162$.

Tako otpornost podupirača na izvijanje iznosi: 


$$
N_{b, k}=X \cdot A \cdot f_{y}=0,162 \cdot 4,93 \cdot 23,5=18,77 \mathbf{k N}
$$

Proračun prema euronormi 3 pokazuje da se otkazivanje nosivosti događa u elastičnom području pri vrlo malim razinama naprezanja, odnosno da podupirač ima vrlo veliku vitkost $(\lambda=209,43)$.

\section{$3 \quad$ Eksperimentalna istraživanja hidrauličnog podupirača [7] [8]}

\subsection{Opis ispitivanja}

Ispitivanje hidrauličnog podupirača provedeno je u Laboratoriju za ispitivanje konstrukcija Zavoda za tehničku mehaniku Građevinskog fakulteta Sveučilišta u Zagrebu. Duljina pri kojoj je provedeno ispitivanje je maksimalna duljina u istegnutom stanju koja iznosi $I_{\max }=3,50 \mathrm{~m}$.

Ispitivanje je provedeno u skladu s normom HRN EN 1065:2002 (Prilagodljivi teleskopski čelični potpornji Proizvodne specifikacije, oblikovanje i dokaz putem proračuna i ispitivanja). Navedena norma odnosi se na klasične podupirače, a metode ispitivanja definirane u njoj korištene su i za ispitivanje ovog hidrauličnog podupirača. Ispitivanje nosivosti cijelog podupirača provedeno je prema točki 10.2 te norme (Test method for the prop strength).
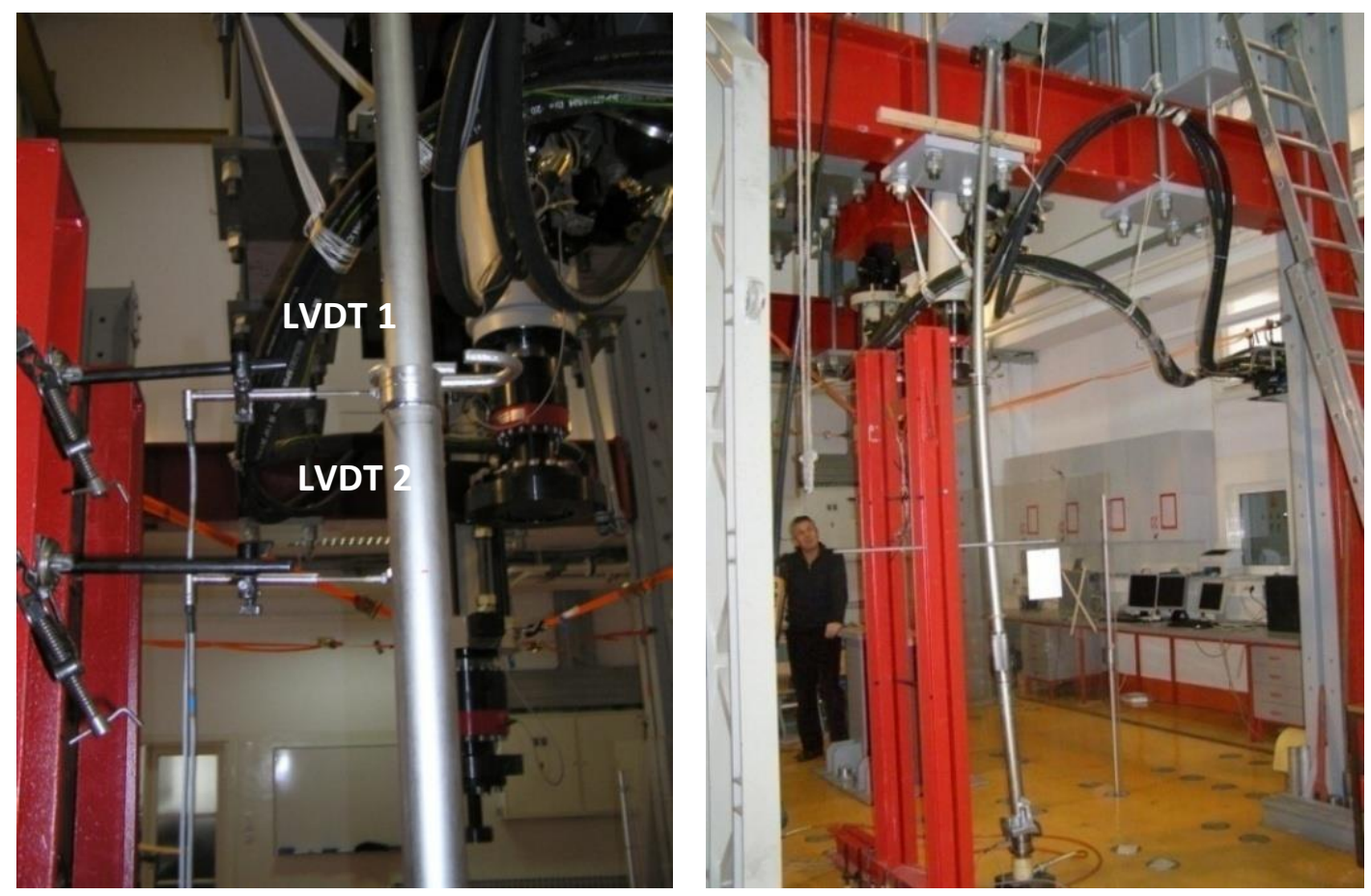

\section{Slika 10 - Ispitivanje hidrauličkog podupirača a) mjerna mjesta za mjerenje pomaka LVDT1 i LVDT 2 b) podupirač u izvijenom stanju}

Prilikom ispitivanja, mjerena je sila opterećivanja i dva horizontalna pomaka: jedan na mjestu spoja gornje i radne cijevi, a drugi na polovini ukupne duljine. Sila je mjerena dozom nosivosti $500 \mathrm{kN}$, a pomaci induktivnim osjetilima (LVDT1 i LVDT2). Način ispitivanja hidrauličnog podupirača vidi se na slici 10.

\subsection{Rezultati ispitivanja}


Rezultati ispitivanja hidrauličnog podupirača prikazani su na slici 11. Maksimalna sila pri kojoj je došlo do popuštanja podupirača iznosila je $F_{\mathrm{kr}}=20,08 \mathrm{kN}$. Kako ispitivanje nije provedeno kontrolom pomaka, nije se mogla dobiti silazna grana na dijagramu sa Slike 11 pa je ekstrapolacijom na dijagramu sila - pomak dobivena veličina pomaka $f_{\max } \approx 80 \mathrm{~mm}$ u trenutku maksimalne sile. Tako je podupirač $\mathrm{u}$ tom trenutku uz $f_{\max } \approx 0,08 \mathrm{~m}$ opterećen $\mathrm{i}$ momentom savijanja $M_{\max }=1,61 \mathrm{kNm}$.

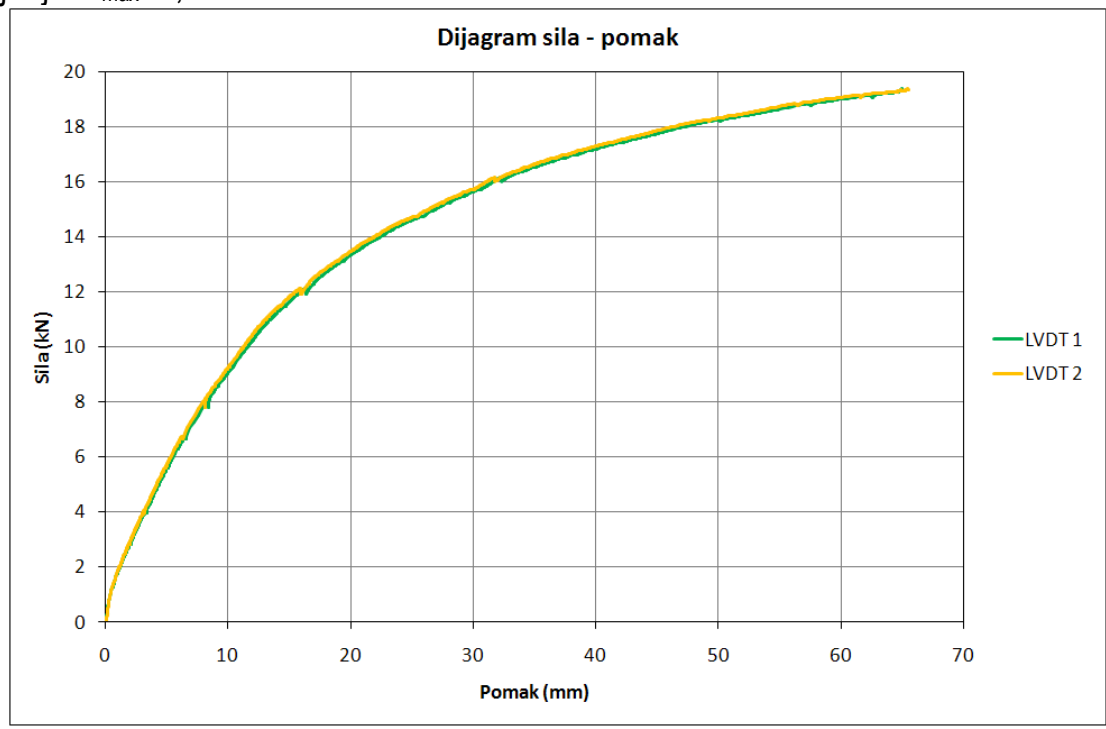

Slika 11 - Dijagram sila - pomak (LVDT1 i LVDT2)

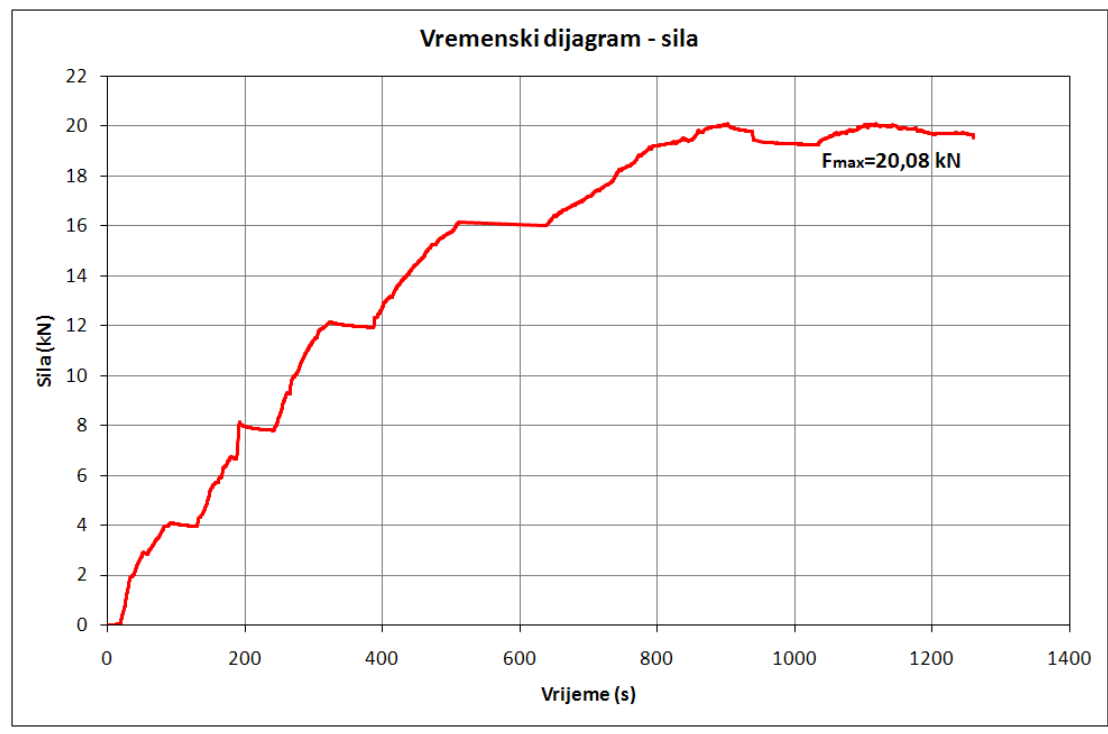

Slika 12 - Vremenski tijek nanošenja sile

Maksimalna naprezanja u cijevi s bruto površinom iznose:

$\sigma_{\operatorname{maxmin}}=\frac{F_{\mathrm{kr}}}{A_{\mathrm{br}}} \pm \frac{M_{\max }}{W_{\mathrm{br}}^{\text {el }}}=40,76 \pm 312,71$

$\sigma_{\max }=353,51 \mathrm{MPa}$ (tlak) $\quad \sigma_{\min }=-271,91 \mathrm{MPa}$ (vlak).

Ako se izračunaju naprezanja na neto površini poprečnog presjeka, dobiva se: 
$\sigma_{\operatorname{maxmin}}=\frac{F_{\mathrm{kr}}}{A_{\text {neto }}} \pm \frac{M_{\max }}{W_{\mathrm{n}}^{\text {el }}}=53,15 \pm 530,00$

$\sigma_{\max }=583,20 \mathrm{MPa}$ (tlak) $\sigma_{\min }=-476,80 \mathrm{MPa}$ (vlak).

Iz prethodnoga, proizlazi zaključak da materijal od kojega su izvedene ispitivane cijevi ima veću granicu tečenja od materijala koji je pretpostavljen kao čelik klase S 235.

\section{Usporedba rezultata}

Laboratorijskim ispitivanjem dobivena je kritična sila $F_{\mathrm{kr}}=20,08 \mathrm{kN}$. Najbliža toj vrijednosti je kritična sila dobivena proračunom prema euronormi 3 , koja iznosi $F_{\mathrm{kr}}=18,77 \mathrm{kN}$. Analitičkim postupkom (rješavanjem diferencijalne jednadžbe) dobivena je najveća kritična sila, a proračunom računalnim programom SOFiSTiK najmanja kritična sila. U tablici 3 prikazana je usporedba teorijski i eksperimentalno određenih kritičnih sila. Iz tablice 3 vidi se da su proračuni metodom konačnih elemenata i prema EC3 sigurniji u odnosu na analitički postupak i eksperimentalno određenu kritičnu silu.

\section{Tablica 3 - Usporedba dobivenih kritičnih sila}

\begin{tabular}{|l|c|}
\hline metoda određivanja kritične sile & veličina kritične sile $\mathrm{F}_{\mathrm{kr}}(\mathrm{kN})$ \\
\hline Analitički postupak & 22,90 \\
\hline Metoda konačnih elemenata - SOFiSTiK & 17,50 \\
\hline Proračun prema EC3 & 18,77 \\
\hline Eksperimentalno & 20,08 \\
\hline
\end{tabular}

\section{Zaključak}

U radu su prikazana tri različita računska postupka određivanja kritične sile izvijanja (gubitka stabilnosti) hidrauličnog podupirača. Rezultati tako dobivenih sila uspoređeni su s rezultatima ispitivanja.

Proračunom prema euronormi 3 najviše se približilo vrijednosti kritične sile dobivenoj eksperimentalnim ispitivanjem. $U$ proračunu je način obrade cijevi pretpostavljen kao hladno oblikovanje kojemu odgovara linija izvijanja "c". Linijom izvijanja uzimaju se u obzir nesavršenosti i odstupanja (geometrijska i strukturalna).

Analitičkim postupkom dobivena kritična sila ima najveću vrijednost. Razlog tome je zanemarivanje početne nesavršenosti tijekom proračun, zbog jednostavnijeg dobivanja rješenja. Odnosno, analitički izraz obrađuje idealno ravni štap, bez geometrijskih i strukturnih nesavršenosti. Koeficijent duljine izvijanja štapa $(\mu=0,95)$ potvrđuje da je proračunom dobivena veća kritična sila, nego eksperimentalnim postupkom.

Obradom podataka u računalnom programu SOFiSTiK dobivena je najmanja vrijednost kritične sile. Ta vrijednost dobivena je analizom pod pretpostavkom početne nesavršenosti cijevi koja obuhvaća ekscentricitet zbog spoja dviju cijevi, ekscentricitet zbog zakrivljenosti cijevi i ležajni ekscentricitet. Iz navedenih razloga slijedi stroži kriterij dobiven za kritičnu silu.

\section{Literatura}

[1] HRN EN 1065:2002: Adjustable telescopic steel props - Product specifications, design and assessment by calculation and tests

[2] Šimić, V.: Otpornost materijala II, Školska knjiga, Zagreb, 1995.

[3] http://www.wolframalpha.com/, 14.09.2012. 
[4] Tutorial SSD/SOFiPLUS, Version 2010.

[5] Androić, B.; Dujmović, D.; Džeba, I.: Metalne konstrukcije 1, Institut građevinarstva Hrvatske, Zagreb, 1994.

[6] HRN EN 1993-1-1:2008 (Eurokod 3): Design of steel structures - Part 1-1: General rules and rules for buildings

[7] Mujkanović, N.: Završni rad, Građevinski fakultet Sveučilišta u Zagrebu, 2012.

[8] Krolo, J.: Izvješće o ispitivanju hidrauličkog podupirača, Građevinski fakultet Sveučilišta u Zagrebu, 2012. 